\title{
The Aesthetic Value and Moral Education Functions of General Musical Education Based on the Curriculum of "Art of Singing"
}

\author{
Hua Li ${ }^{1}$, Xiaofeng $\mathrm{Liu}^{2, *}$ \\ ${ }^{1}$ Department of Music, University of Shanghai for Science and Technology, shanghai, China \\ ${ }^{2}$ College of Communication and Art Design, University of Shanghai for Science and Technology, \\ Shanghai, China \\ *Corresponding author
}

Keywords: Course, Aesthetics, Moral education, Value, Function.

\begin{abstract}
Instructions for avoiding misunderstandings of aesthetic education is stated through the general musical course-Art of Singing. The course exerts a very positive influence on cultivation of students' musical interest, helping students to develop positive sensibility quality, and thus realizing the aesthetic and moral educational values of general musical education.
\end{abstract}

\section{Introduction}

Although categorized as one of the aesthetical course, music also has its significance on moral education, which helps the positive sensibility quality to be gradually developed among campus students through musical practices. As one of the general courses in university campus, the Art of Singing has the dual responsibility of aesthetical and moral functions.

\section{The aesthetical value of general musical course}

"People oriented" - the course content kept up with the times, while methods diversified. The selection for course content shall reflect the spirit of contemporary era and future outlook, and also accord with the interests of students. For instance, the interests for pop music among campus students now overweighs that for classical one, the teachers should increase the content proportion of pop music on class, or add on appreciation and analysis parts for popular musical TV shows like Voice of China and I Am the Singer, etc. More attention should be paid on the class delivery diversity, like creating relaxing and casual class atmosphere, importing new lessons through various ways, displaying vocal and instrument skills, as well as applying more vivid teaching languages to interest the audience. Meanwhile, it's also practical to collect some relevant stories, to set some intriguing games - singing relay, imitation show- to help concentrate the students' attention, and improving the efficiency as well.

"Teaching in accordance with aptitude", creating platforms which allow students to display talents. Many students have extraordinary specialties in vocal performing, the teachers should regularly acknowledge the song preference of student and give them chances to display their specialties. It could also help to develop confidence among students by imitating the musical TV show- Voice of China. Through mutual comments and communication, the musical aesthetical capability could be dramatically improved.

Heuristic education, fostering creative ability. Musical composition is a kind of effective activity that cultivates inner hearing, enriches imagination and develops creative thinking. In the course Art of Singing, some basic stave knowledge and music theories are also involved, and students are encouraged to walk on the stage, create simple melodies, fill in the lyrics, try to compose some ditties and adapt the lyrics according to music, etc., thus to promote the creativity of students.

"Less obscure professional skills training, more aesthetical appreciation practice". The main purpose for university general musical education should be developing and improving personality 
and psychological heath of students, rather than purely producing academic artist with professional skills. In the process of singing courses, if teachers pay too much attention on vocal methods as well as articulation and enunciation, while neglecting the importance of recreation and performance details of songs, the result would turn out that the students could just simply delivery the song, but the in-depth aesthetical profound meanings are usually failed to be expressed. This teaching method will lead to a consequence that the attention of student would be all paid on the vocal skills, while their ability for aesthetical appreciation are less developed, let alone their character and personality being molded.

\section{The moral education functions of general musical course}

Exploring and creating course content for moral education. University teachers are supposed to keep in mind the sense of moral education, to attentively consider and plan the course content, dig deeply out the moral parameter, explore the teaching methods combined with moral education, so that each class will involve moral education content. For instance, the song I Love You China, sung by Ping An-one competitor from musical TV show Voice of China- could be taken as a specimen in singing course. Just as part of the lyrics -"I love you China, my dear mother"- indicates, student who perform and analyze this very song would be likely to feel the love for their beloved country just as that for their dear mother. In addition, school anthem appreciation could also be a part of course content, so that students could have a better understanding of the humanistic spirit and school mission that their university behold, thus more cherish and honor their school.

Providing diversified methods for moral education. Multiple teaching methods should be applied to stimulate the interest and develop intelligence of students. Moral education should also be infiltrated. Some stories and anecdotes of famous musicians could be told during the class. For example, while displaying the song "Teacher, I Always Miss You", we could initially tell the story that how Liao Changyong- the famous contemporary musician- gradually achieve his personal success from a poor child out of rural regions, under the assistance and guidance of his mentor Zhou Xiaoyan. After having a rough picture about the musician, it would be easier for students to feel in person the touching emotion and the China's precious tradition virtue- Honoring the teacher and respecting his teaching.

Singing relay is a kind of competing group game, which helps to increase the class interaction and engagement, as well as the sense of collective honor and cooperative spirit. Games with a bit difficulty also help to promote the perseverance and anti-frustration toughness of students.

Dancing skills could also be introduced in the help for music displaying. Taking The Dance of Yao People- the dance music from one of China's minor ethnic group Yao- as example, teachers could show some basic dancing movement to help students feel the life habit of the ethnic group- featuring diligent, kind-hearted and being good at singing and dancing- that living in the remote south of China,

Utilizing the aesthetic value of music for moral education. Music itself has many aesthetic values, which can bring vivid emotional experience to student, helping them to feel the inspiration and edification, along which the intention for moral education could also be satisfied. While appreciating the poem-song Chun Xiao- the dawn of a spring day, teachers could initially brief the background of the composer Meng Haoran, then read the poem with deep emotion along with the Chinese musical instrument - zither. The student could probably have a deeper understanding about the perfect resonance between the melody and the lyrics, experience the profound, smooth and rich emotions of the song, and enhance the recognition and confidence for Chinese traditional culture. While dialoguing and resonating with ancient artists trough art works, the ideological level as well as the personality of students could be promoted, so are the lofty moral standard and the noble spiritual realm.

Using teachers' personalities for unconscious moral education. Those teachers who truly devote themselves in music educational cause should be equipped with characters like lofty pursuit, noble sentiments, rich knowledge and serious attitude, and could genuinely set examples for student. Teachers' neat and clean dress, natural and dignified manners, vivid and humorous language, 
passionate and emotional singing and accurate and skillful conducting, will exert a profound while unconscious influence on student for all the time. The dignity and moral trait enshrined by teachers could be passed on to students and accompany them for the rest of their lives. For instance, teachers could display their own school anthem, their intriguing anecdotes and their feeling of missing for their mentors and schoolmates to their students, thus inspiring the students to respect their teachers, honor their alma mater and cherish their relationships with their schoolmates.

\section{Avoiding the misunderstandings about the aesthetical value and moral educational function of general musical education.}

General musical education should not shoulder too much moral educational burdens while neglecting the aesthetical value. The purpose of moral education through music is to take good advantage of its unique form and means, to foster modernist that pursues the truth, kindness and beauty, and to explore the boundary of beauty. Due to the historical reason, people have long tend to focus on the exterior values attached to musical class, while ignoring its core interior value, i.e. the value for aesthetics. Recently many universities are advocating ideological and political education, which overshadows all the current existing curriculums in campus. If teachers follow this pattern and ignore the right unconscious manners, it could probably antagonize the student, and thus eroding the significance of musical education.

The aesthetical and moral functions of general musical education share the same spirit with each other; it's not proper to talk about one while neglecting the other. Initially, the sense of aesthetics and morality share the same emotional base. The aesthetical feeling is a kind of positive emotional experience based on psychological joviality, while fine moral emotions are established over positive joviality, therefore, those who have good sense of aesthetics tend to have decent moral emotion. Second, the sense of aesthetics and morality shares the same recognition. Aesthetical judgment is a crucial part of musical education. On the internet, recently there prevailed a song called The Black Saturday, which resulted in several suicide cases from those who suffer from psychopaths, and some normal people were also diagnosed with depressive disorder after listening to the song. Whether those songs that propagate individualism and decadent attitude are beautiful or not, whether those singers that turn themselves into a creature between human and monster by plastic surgery are beautiful or not, etc, those questions are to be answered by the students led by teachers after logical analysis over its content and form. Only when one can properly identify beauty from ugliness through appropriate recognition about the principles of creating beauty, one can genuinely pursue the beauty while abandon the opposite. Beauty is always true and kind, while pursuing beauty is pursuing truth and kindness as well.

Although beauty has various manifestations, they all share the same intrinsic quality. Therefore, during the music classes, the aesthetical judgment could be extended to the realm of natural world, human society, daily life, other art forms, and even human beings ourselves. Music teachers should take advantage of wide range aesthetical judgments to properly guide students to establish positive aesthetical standards, thus laying solid foundation for fostering decent moral traits of students.

\section{Acknowledgement}

Fund project : This paper is the result of the research project of teachers' teaching development in University of Shanghai for Science and Technology (project number: CFTD17022Z).

\section{References}

[1] HAN Lina. The moral education functions of music education in university [J]. Political and Ideological Education, 2014,03:93-96. 
[2] WANG Xinxue, CHEN Delin. The construction of the music moral education model of universities under the "great thinkers" view [J]. University Party Building and Ideological Education, 2014,22:32-33.

[3] CHEN Liu. The university general music education -starting with the effect and feedback of the University's Music from Shangrao norm college [J]. People Music, 2011,02:56-58.

[4] DING Peng. Discussion of curriculum architecture strategy of Music education [J]. China Education, 2015,S2:290-291.

[5]WANG Donghong. Thinking about contemporary music education [J]. Big Stage, 2013,11:161-162. 